\title{
Efektivitas Penyaluran Program Bantuan Presiden Produktif Usaha Mikro, Kecil, dan Menengah pada Masa Pandemi Covid-19 di Kabupaten Sleman Daerah Istimewa Yogyakarta
}

\author{
The Effectiveness of Productive Presidential Assistance Program \\ Distribution for Micro, Small, and Medium Enterprises during the \\ Covid-19 Pandemic in Sleman Regency, Special Region of Yogyakarta
}

\author{
Nadia Fitri Wijayaningsih, Eko Priyo Purnomo, Aqil Teguh Fathani, Lubna Salsabila \\ Program Studi Ilmu Pemerintahan, Univesitas Muhammadiyah Yogyakarta \\ Gedung Ki Bagus Hadikusumo E3 Lantai 1, Kampus Terpadu UMY \\ JL. Brawijaya, Kasihan, Bantul, Yogyakarta 55183 \\ Telp: +62 274387656 Ext. 120, Fax: +62 274387646 \\ Email: nadfitriw@gmail.com, eko@umy.ac.id, aqil.teguh.psc19@mail.umy.ac.id, \\ lubna.salsa@gmail.com
}

(Diterima 02/06/21; Disetujui 10/09/21)

\begin{abstract}
The purpose of this study was to determine whether the presidential assistance carried out by the Department of Cooperatives and Small Medium Enterprises and Micro (MSMEs) Sleman Yogyakarta to MSMEs was right on target or not with the procedures or policies set by the government. The occurrence of a contraction in the economic rate in Sleman is indicated by the Gross Regional Domestic Growth rate data, which shows a contraction from 2019 to 2020. In following up on these problems, the government provided government assistance in Productive Micro Business Assistance or Productive Presidential Assistance to MSMEs affected by the Covid-19 pandemic. The Assistance Program was given considering the Regulation of the Minister of Cooperatives, Small and Medium Enterprises of the Republic of Indonesia Number 6 of 2020 concerning general guidelines for distributing government assistance to micro-enterprises in the national economic recovery as a form of facing threats to the national economy to saving the national economy during the Covid-19 pandemic. This study uses qualitative methods by using data sources used by researchers are secondary data. The results showed that the Presidential Assistance given to MSME actors was less effective due to the problematic distribution of Banpres, namely at the stage of proposing prospective recipients, cleaning data, and validating data from prospective beneficiaries. In this study, the authors recommend a centrally-based online form in proposing potential beneficiaries.
\end{abstract}

Keywords: MSMEs, economy, Banpres, covid-19 pandemic.

\section{Abstrak}

Tujuan penelitian ini adalah untuk mengetahui apakah Bantuan Presiden (Banpres) yang dilakukan Dinas Koperasi dan Usaha Menengah Kecil dan Mikro Sleman Yogyakarta kepada UMKM tepat sasaran atau tidak dengan prosedur atau kebijakan yang telah ditetapkan pemerintah. Terjadinya kontraksi laju ekonomi di Sleman ditunjukkan dengan adanya data 
laju Pertumbuhan Domestik Regional Bruto yang menunjukkan kontraksi dari 2019 ke 2020. Dalam menindaklanjuti permasalahan tersebut, pemerintah memberikan Bantuan Produktif Usaha Mikro atau Bantuan Presiden Produktif kepada UMKM yang terdampak dalam pandemi Covid-19. Program Bantuan tersebut diberikan menimbang dengan adanya Peraturan Menteri Koperasi, Usaha Kecil, dan Menengah Republik Indonesia Nomor 6 Tahun 2020 tentang pedoman umum penyaluran bantuan pemerintah bagi pelaku usaha mikro dalam pemulihan ekonomi nasional sebagai bentuk menghadapi ancaman perekonomian nasional hingga penyelamatan ekonomi nasional pada masa pandemi Covid-19. Penelitian menggunakan metode kualitatif dengan menggunakan sumber data yang digunakan peneliti adalah data sekunder. Hasil penelitian menunjukkan terdapat Banpres yang diberikan kepada pelaku UMKM kurang efektif dikarenakan penyaluran tersebut bermasalah, yaitu pada tahap pengusulan calon penerima, pembersihan data, dan validasi data dari calon penerima bantuan. Dalam penelitian ini, penulis merekomendasikan formulir online berbasis terpusat dalam pengusulan calon penerima bantuan.

Kata Kunci : UMKM, ekonomi, Banpres, pandemi covid-19

\section{PENDAHULUAN}

Tujuan penelitian dilakukan untuk mengetahui apakah Bantuan Presiden (Banpres) yang dilakukan Dinas Koperasi dan UMKM Sleman Yogyakarta kepada Usaha Mikro, Kecil, dan Menengah tepat sasaran atau tidak dengan prosedur atau kebijakan yang telah ditetapkan pemerintah. Hal ini bisa dijadikan sebagai monitoring dan evaluasi bagi pemerintah daerah agar pemberian Banpres dapat diberikan kepada UMKM yang betulbetul membutuhkan bantuan. Monitoring merupakan penilaian yang dilakukan secara terus menerus sedangkan evaluasi yakni penilaian yang dilakukan secara berkala terhadap efisiensi program (Hamdala \& Esabella, 2020). Fokus penelitian tertuju kepada penerima Banpres terhadap berjalannya bisnis UMKM pada masa pandemi Covid-19. Pada awal 2020, Indonesia dihadapkan pada pandemi virus Covid-19 yang berdampak pada seluruh aktivitas dalam negeri maupun internasional. Pandemi Covid-19 berdampak bagi berjalannya perekonomian nasional yang mayoritas merupakan pelaku Usaha Mikro, Kecil, dan Menengah (UMKM). Dampak tersebut sangat signifikan terhadap tatanan pada perekonomian domestik negara (Pakpahan, 2020). Untuk menindak lanjuti dampak yang terjadi, pemerintah memberikan Bantuan Produktif Usaha Mikro atau Banpres kepada pelaku UMKM di seluruh Indonesia. Bantuan tersebut diberikan dengan pertimbangan Peraturan Menteri Koperasi, Usaha Kecil, dan Menengah Republik Indonesia Nomor 6 Tahun 2020 tentang Pedoman Umum Penyaluran Bantuan Pemerintah bagi Pelaku Usaha Mikro Untuk Mendukung Pemulihan Ekonomi Nasional Pada Masa Pandemi Covid-19.

Teori yang digunakan dalam penelitian yaitu dari Alfrian \& Pitaloka (2020) yang menjelaskan bahwa UMKM merupakan salah satu sektor perekonomian nasional yang harus diupayakan dan memiliki posisi yang penting dalam keberlangsungan perekonomian Indonesia (Leckel et al., 2020). Peran UMKM dibutuhkan dalam meningkatkan laju perekonomian dengan adanya dukungan dari pemerintah melalui kebijakan pemerintah (Sari et al., 2020). Implementasi kebijakan merupakan aktivitas yang dilakukan oleh pemerintah, individu, kelompok, maupun swasta yang diarahkan sesuai dengan sasaran atau tujuan dari program berdasarkan prosedur. Pengembangan UMKM bisa terlaksana secara maksimal melalui peran pemerintah yang optimal dan efektif sebagai fasilitator, regulator, serta katalisator. Dengan adanya ketiga peran tersebut, pembangunan fasilitas untuk UMKM yang dilakukan oleh pemerintah dapat meningkatkan kualitas produksi yang 
jauh lebih baik dan mampu bersaing secara internasional (T. G. Putra, 2015). Peran pemerintah tersebut dapat tercapai dengan adanya monitoring serta evaluasi dari pemerintah, dalam hal mencermati pelaksanaan Banpres kepada pelaku UMKM yang membutuhkan. Banpres produktif kepada UMKM merupakan bantuan pemerintah yang berbentuk bantuan langsung tunai (Satispi et al., 2021; Sugiri, 2020).

Kebijakan Banpres dilakukan dengan pertimbangan data laju perekonomian yang terjadi pada 2020 dan diukur menggunakan nilai Produk Domestik Regional Bruto (PDRB). Laju perekonomian di Daerah Istimewa Yogyakarta menggunakan metode $y$-on-y yaitu metode yang dilakukan dengan membandingkan periode tahun tertentu dengan periode yang sama dengan tahun sebelumnya. Terjadi kontraksi atau penurunan yang drastis pada 2020 yang disebabkan oleh pandemi Covid-19 yang berdampak besar pada pertumbuhan ekonomi. Kontraksi yang terjadi pada laju ekonomi tersebut, ditunjukkan dengan pertumbuhan dan perkembangan UMKM di DIY (Badan Pusat Statistika DIY, 2020).

UMKM di Kabupaten Sleman, Daerah Istimewa Yogyakarta juga mengalami dampak usaha akibat pandemi Covid-19. Tercatat bahwa adanya kontraksi laju perekonomian pada masa pandemi membuat UMKM terdampak akan usaha mereka (Dinas Koperasi dan UMKM Sleman, 2020). Kabupaten Sleman memiliki 17 Kecamatan, 86 Desa, dan 1.212 Dusun (Pemerintah Kabupaten Sleman, 2016). Dalam menindaklanjuti hal tersebut, pemerintah mengeluarkan kebijakan Banpres secara bertahap. Menurut data dari Dinas Koperasi dan UMKM Sleman (2020), penerima bantuan presiden senilai 2,4 juta diberikan kepada 2.162 UMKM. Bantuan tersebut diberikan kepada pelaku UMKM yang telah dipilih melalui penyaringan dengan menimbang berbagai persyaratan dengan syarat tertentu.

Pada 2016, ada lebih dari 65 juta UMKM yang tersebar di seluruh Indonesia. Jumlah tersebut terus meningkat. Pada 2017, jumlah UMKM mencapai 62,9 juta dan pada 2018, jumlah UMKM mencapai 64,2 juta. Hingga 2021, jumlah UMKM akan mencapai 65 juta dan terus meningkat serta melakukan diversifikasi di berbagai bidang usaha (Christy, 2021). Kategori UMKM di bidang Perdagangan dan Jasa di Kabupaten Sleman menunjukkan bahwa lebih dari 50\% usaha UMKM terdapat di Sleman. Kedua, di bidang kuliner dari makanan tradisional hingga modern, sebesar 27\% kuliner terdaftar dalam UMKM di Sleman. Kedua kategori UMKM tersebut merupakan kategori yang memiliki dampak besar dalam masa pandemi Covid-19. Kategori bidang perdagangan dan kuliner berdampak besar bagi pelaku UMKM dikarenakan adanya pembatasan sosial yang mengakibatkan penjualan usaha turun. Pembatasan sosial ini dilakukan dengan mengkapasitasi orang yang berada dalam ruangan hingga tata letak meja dan kursi dalam ruangan dibatasi dan diberikan jarak yang dianjurkan (Chandra, 2020).

Komparasi efektivitas program bantuan presiden di Kabupaten Sleman dengan di daerah lain menunjukkan kesenjangan terhadap pengusulan calon penerima bantuan. Program Banpres di Kabupaten Sleman dengan Kota Surabaya, Kecamatan Gubeng memiliki efektivitas yang berbeda. Kota Gubeng dalam penyaluran bantuan memiliki efektivitas yang baik dalam implementasi BPUM atau Banpres. Program Banpres di Sleman memiliki komunikasi atau informasi yang kurang jelas dan informasi bantuan hanya terdapat di sosial media yaitu Instagram dan portal resmi. Jika dibandingkan dengan implementasi Banpres di Gubeng, kebijakan publik dimanfaatkan dengan baik dalam kejelasan dan konsistensi untuk kelancaran implementasi program. Selain itu, penyaluran Banpres di Gubeng lebih terstruktur sesuai Standard Operating Procedure (SOP) dan memiliki tranparasi yang cukup baik (Rozzaq \& Widiyarta, 2021; Setiawana et al., 2021). Hal ini 
ditandai dengan sikap, intruksi, dan komitmen dalam tindak lanjut suatu kebijakan. Pertama, kognisi yaitu pemahaman aparatur di kabupaten, kecamatan, kelurahan, dan RT atau RW terhadap kebijakan program Banpres kepada UMKM. Kedua, arahan dari kabupaten terhadap penyelenggaraan dan penyaluran Banpres kepada pelaku UMKM yang ingin mendapatkan bantuan tersebut.

Kajian lain yang memiliki efektivitas penyaluran bantuan tidak tepat sasaran yaitu di Kelurahan Purwosari yang dinilai kurang efektif akibat beberapa permasalahan. Pertama, kurangnya data yang akurat atau detail, tidak diperbaharui, serta kurangnya bimbingan teknis yang didapatkan terkait dengan program pedataan. Kedua, dalam kebijakan Menteri Sosial Nomor 54/HUK/2020 tidak dijelaskan secara rinci mengenai kriteria yang mendapatkan bantuan (Mufida, 2021). Tidak efektifnya penyaluran bantuan tersebut memiliki kesamaan dengan di Kabupaten Sleman, di mana kurang terdapatnya informasi yang jelas terkait dengan bimbingan teknis pendataan calon pengusulan penerima bantuan di kelurahan. Kelurahan memiliki peran yang sangat besar terhadap proses pendataan dan pendapatan informasi dikarenakan kelurahan atau desa merupakan wilayah yang bisa dilakukan dengan musrenbang. Tepat sasaran bantuan dialami di desa Nagari Talang Anau, dengan menggunakan sistem musrenbang sebagai sarana sosialisasi bantuan langsung tunai, kebijakan bantuan langsung tunai telah di-monitoring dengan baik hingga tahap verifikasi serta penyalurannya (Valentina et al., 2020).

Dalam penyaluran kepada pelaku UMKM, Banpres tidak tepat sasaran, terlebih bagaimana proses dan cara pemerintah menyalurkan bantuan tersebut kepada UMKM (Sari et al., 2020; Nur Aini \& Mundir, 2020). Penyaluran bantuan tersebut ditandai dengan persyaratan bahwa masing-masing pelaku UMKM yang ingin menerima bantuan harus memiliki usaha sendiri. Berdasarkan pernyataan Bima Yudhistira selaku ekonom dari Institute for Development of Economics and Finance (2021), pemerintah tidak memiliki waktu dalam memverifikasi data yang sangat banyak sehingga menyebabkan potensi tidak tepat sasaran bagi pelaku UMKM yang sebenarnya menerima pinjaman bank tetapi mengajukan untuk mendapatkan dana hibah (Jannah, 2020; Priyanto et al., 2020). Banpres atau BPUM memiliki beberapa kriteria dan persyaratan bagi calon penerima bantuan (Peraturan Menteri Koperasi, Usaha Kecil, Dan Menengah Republik Indonesia Nomor 6 Tahun 2020 Tentang Pedoman Umum Penyaluran Bantuan Pemerintah Bagi Pelaku Usaha Mikro Untuk Mendukung Pemulihan Ekonomi Nasional Pada Masa Pandemi Covid-19, n.d.), diantaranya adalah sebagai berikut.

1) Pelaku yang memiliki usaha mikro.

2) Pelaku usaha tidak sedang menerima kredit atau pembiayaan dari bank.

3) Memiliki usaha yang dibuktikan dengan surat usulan dari pengusul bantuan dari Dinas UMKM.

4) Bukan anggota dari Aparatur Sipil Negara, Pegawai BUMN, Pegawai BUMD, Kepolisian, dan Tentara Nasional.

Kontribusi penelitian terhadap bidang ini sebagai bentuk monitoring penyaluran Banpres atau BPUM agar dalam penyaluran yang memiliki rentang waktu tertentu atau memiliki program per-gelombang dapat dilakukan secara transparan dan baik oleh Dinas Koperasi dan UMKM Sleman, terutama dalam pengusulan calon penerima bantuan. Selain itu, usulan lain dari penulis sebagai bentuk kontribusi yaitu pada pengusulan calon penerima Banpres agar dilakukan dari tingkat kelurahan hingga penyampaian data ke dinas lebih ketat dan transparan terutama pada persyaratan yang perlu semakin spesifik. 
Peneliti menggunakan metode penelitian secara kualitatif dengan didukung data sekunder yang diperoleh dari data statistik serta data pendukung seperti hasil penelitian terdahulu untuk mengetahui perbandingan kebijakan bantuan presiden dari tahun sebelumnya. Penelitian menggunakan metode kualitatif eksploratif yaitu metode dengan menjelaskan serta menginvestigasi lebih mendalam terhadap proses, makna, serta konteks yang akan diteliti serta memberikan keleluasaan bagi peneliti untuk menganalisis kasus atau multikasus secara mendalam dan detail (Al-Hamdi et al., 2020). Dalam penelitian ini, peneliti fokus membahas efektifitas penyaluran program Banpres kepada UMKM di Kabupaten Sleman, Provinsi Daerah Istimewa Yogyakarta.

\section{TINJAUAN TEORITIS}

Peran Usaha Mikro, Kecil, dan Menengah (UMKM) terhadap Ekonomi Nasional

Pemerintah Indonesia menetapkan peraturan dasar bagi Usaha Menengah Kecil dan Mikro sebagaimana diatur dalam Undang-Undang Nomor 20 Tahun 2008 tentang Usaha Mikro, Kecil, dan Menengah. UMKM adalah usaha yang dijalankan oleh perorangan, rumah tangga, atau badan usaha kecil (Tarmizi, 2018; Leckel et al., 2020). Sedangkan usaha yang tidak termasuk UMKM dikategorikan usaha besar, yaitu usaha ekonomi produktif yang dilakukan oleh badan usaha dengan kekayaan bersih atau pendapatan penjualan tahunan lebih besar dari usaha menengah, yang meliputi badan usaha milik negara atau swasta nasional, usaha, dan bisnis asing yang melakukan kegiatan ekonomi di Indonesia. UMKM memiliki ciri khas yang membedakan dengan usaha lain yaitu omzet, kekayaan bersih, jumlah tenaga kerja, jumlah modal awal, pembinaan, dan pajak (Undang-Undang Republik Indonesia Nomor 20 Tahun 2008 Tentang Usaha Mikro, Kecil, dan Menengah, n.d.).

UMKM merupakan kegiatan usaha yang dilakukan oleh masyarakat yang berperan untuk mewujudkan stabilitas ekonomi nasional serta dapat meningkatkan pendapatan dan pemerataan ekonomi bagi masyarakat maupun kegiatan usaha dapat mampu memperluas dan meratakan lapangan pekerjaan bagi masyarakat (Auliya \& Arif, 2021). Usaha mikro yaitu usaha yang dilakukan oleh perorangan dan memiliki hasil bersih sebesar Rp50 juta hingga Rp300 juta dengan total kekayaan usaha paling banyak Rp50 juta (tidak termasuk aset tanah dan bangunan. Usaha kecil merupakan usaha yang dilakukan oleh perorangan dan bukan merupakan cabang usaha yang dimiliki bagian langsung atau tidak dengan usaha menengah dan usaha kecil memiliki hasil Rp300 juta hingga Rp2,5 miliar. Usaha kecil adalah usaha ekonomi produktif yang berdiri sendiri, yang dilakukan oleh orang perseorangan atau badan usaha yang bukan merupakan anak perusahaan atau cabang perusahaan yang dimiliki, dikuasai, atau menjadi bagian baik langsung maupun tidak langsung dari usaha menengah atau usaha besar (Undang-Undang Republik Indonesia Nomor 20 Tahun 2008 Tentang Usaha Mikro, Kecil, Dan Menengah, n.d.)

Sedangkan usaha menengah adalah usaha ekonomi produktif yang berdiri sendiri, yang dilakukan oleh orang perseorangan atau badan usaha yang bukan merupakan anak perusahaan atau cabang perusahaan yang dimiliki, dikuasai, atau menjadi bagian baik langsung maupun tidak langsung dengan usaha kecil atau bisnis besar. Kekayaan bersih usaha menengah tidak termasuk tanah dan bangunan yang telah mencapai lebih dari Rp500 juta per tahun (definisi UMKM). Usaha kecil atau menengah (UKM) juga memiliki kriteria omzet penjualan lebih dari Rp2,5 miliar hingga Rp50 miliar per tahun (Undang-Undang Republik Indonesia Nomor 20 Tahun 2008 Tentang Usaha Mikro, Kecil, Dan Menengah, n.d.). 
Sektor perekonomian nasional memberikan posisi kepada UMKM dalam keberlangsungan ekonomi Indonesia sebagai posisi yang penting (Alfrian \& Pitaloka, 2020). Dalam keberlangsungan perekonomian Indonesia, selain UMKM juga terdapat UKM yang memiliki peran yang penting dalam perekonomian nasional (Soetjipto, n.d.). UMKM termasuk ke dalam sektor ekonomi nasional yang harus dikembangkan serta diberdayakan agar UMKM bisa berkontribusi dalam pertumbuhan ekonomi nasional (Marlinah, 2020). Perlu diketahui bahwa UMKM menjadi salah satu bentuk penopang bagi perekonomian Indonesia sekaligus sebagai penanggulangan kemiskinan (Alauddin, LC, 2019). Didukung oleh data Produk Domestik Bruto, UMKM memberikan sekitar 60\% (Susanti et al., 2020). Perekonomian nasional mengalami dampak yang serius, terutama pada aspek nilai perdagangan pada masa pandemi Covid-19 yang berdampak kepada daya beli masyarakat yang turun (Pakpahan, 2020).

\section{Peran dan Bantuan Pemerintah}

Peran adalah kewenangan yang dihadapi oleh seseorang atau instansi dalam menjalankan kedudukannya sesuai dengan kewajibannya (Soares, 2015). Peran bisa dikelompokkan menjadi pemberdayaan, pelaksana, dan pembida dalam kewajibannya (Ulumiyah et al., 2013). Peran adalah suatu kewajiban yang penting untuk menentukan maju mundurnya suatu program atau kebijakan (Panjaitan et al., 2019). Peran dalam pemerintah merupakan peranan yang diarahkan dalam menciptakan aparatur yang baik dan mampu mengabdi kepada masyarakat dan Negara (Mondong, n.d.).

Peran pemerintah daerah yaitu sebagai fasilitator, regulator, dan katalisator sebagai pengembangan kebijakan atau program pemerintah agar terlaksana dengan optimal dan efektif, ketiga peran tersebut yaitu pembangunan dalam fasilitas yang diperlukan untuk UMKM oleh pemerintah dapat meningkatkan kualitas produksi yang jauh lebih baik dan mampu dalam persaingan internasional (T. G. Putra, 2015). Peran pemerintah daerah yaitu bertanggung jawab terhadap penanganan dampak di masa pandemi Covid-19 terhadap penyaluran bantuan dengan lembaga atau instansi terkait sebagai peranan pemerintah daerah agar lebih terfokus kepada bantuan usaha mikro. Instansi terkait yaitu Dinas Koperasi dan UMKM Kabupaten (Auliya \& Arif, 2021).

Bantuan sosial yaitu bantuan yang dilakukan oleh pemerintah berupa sejumlah uang, sembako, masker, dan handsanitizer (Dewi et al., 2020; Effendi et al., 2020; Purnomo et al., 2021). Pemberian bantuan bertujuan untuk meringankan beban penerima untuk kebutuhan sehari-hari (Santoso et al., 2020). Bantuan Langsung Tunai Dana Desa merupakan bantuan pemerintah dengan sumber anggaran berasal dari APBN berupa uang tunai (Y. P. Putra et al., 2020). Bantuan langsung tunai tanpa syarat merupakan program yang didanai organisasi non-pemerintah dan pemerintah tanpa mempersyaratkan bantuan harus dihabiskan untuk keperluan yang harus dilakukan kepada setiap individu dan rumah tangga, serta bantuan langsung tunai bersyarat merupakan program dengan mengharuskan penerima memenuhi syarat tertentu untuk menerima bantuan (Khomaini, n.d.; Mutiarin et al., 2020). Bantuan Produktif Usaha Mikro (BPUM) merupakan bantuan dari pemerintah berupa uang tunai bagi pelaku UMKM untuk pemulihan ekonomi nasional (Rozzaq \& Widiyarta, 2021). Dalam situasi darurat seperti saat ini, pemerintah Indonesia memberikan banyak bentuk bantuan kepada masyarakat yang terdiri dari Bantuan terhadap UMKM, Bantuan Kartu Prakerja, Subsidi Gaji, Bantuan Langsung Tunai, Bantuan Sosial dan berbagai bantuan lain dari Non-Pemerintah (Wongkar \& Soepeno, 2021) 


\section{Implementasi Bantuan Kepada UMKM}

Implementasi merupakan salah satu tahap dalam proses kebijakan yang marak dibicarakan oleh beberapa pakar (Akib, 2012). Alur dari proses pembuatan suatu kebijakan dimulai dengan adanya isu kebijakan, perumusan kebijakan, hingga implementasi (Lukitasari et al., 2017). Implementasi merupakan salah satu proses yang dilakukan oleh orang atau beberapa orang untuk melaksanakan ide atau gagasan yang telah disetujui bersama agar dengan harapan program atau aktifitas baru dan melakukan sebuah perubahan (Rahmat, 2017). Secara konseptual, implementasi suatu program dalam pemerintah, harus berpedoman pada aturan atau ketentuan yang telah diatur oleh pemerintah (Firdaus \& Rakhmat, 2019). Implementasi merupakan program yang melibatkan upaya dalam proses pembuatan kebijakan untuk mempengaruhi pelaksana kebijakan yaitu sebagai perilaku birokrat (Kembuan et al., n.d.).

Implementasi kebijakan merupakan aktivitas yang dilakukan oleh pemerintah, individu, kelompok, maupun swasta yang diarahkan sesuai dengan sasaran atau tujuan dari program sesuai dengan prosedur atau tidak (Alfrian \& Pitaloka, 2020). Implementasi bantuan kepada masyarakat dipengaruhi oleh kesiapan pemerintah dalam pendistribusian bantuan yaitu pada penggunaan database yang akan digunakan sebagai fasilitator pendataan (Mufida, 2021). Selain itu, menurut (Suari \& Giri, 2021) implementasi suatu bantuan memerlukan mekanisme kebijakan yang baik dan harus terkait dengan penyaluran dana. Salah satu mekanisme kebijakan yang baik dimulai dengan diperlukannya informasi yang dilakukan oleh pemerintah kepada calon penerima bantuan (Maun, n.d.; Valentina et al., 2020). Implementasi bantuan yang tepat sasaran memerlukan peran aktif dari pemerintah dan calon penerima bantuan, yaitu dengan dilakukannya monitoring langsung di lapangan dan membuat sebuah forum seperti musrenbang yang dilakukan desa agar dalam pendataan bersifat transparan dan terbuka bagi calon penerima bantuan.

Dampak bantuan secara sosial yaitu pada penerima calon dengan kriteria yang digunakan pada penerima bantuan pemerintah yang dominan pada kriteria status pekerjaan kepala keluarga. Selain itu status lain dapat digunakan sebagai tolok ukur dalam kriteria ketepatan sasaran bantuan pemerintah, dengan cara memperhatikan status pekerjaan istri, status rumah, dan jumlah tanggungan (Kusumawardhany, 2020). Data hasil yang digunakan dalam kriteria sasaran bantuan dipengaruhi oleh kritera penghasilan, jumlah tanggungan, fasilitas air bersih, dan luas bangunan (Alfiarini \& Primadasa, 2020). Penyaluran bantuan pemerintah menggunakan metode SMART dengan menggunakan beberapa kriteria yaitu status pekerjaan, penghasilan per-bulan, banyaknya tanggungan, status tempat tinggal, listrik, asuransi, dan PKH (Hutagalung et al., 2021). Selain itu, bantuan yang disalurkan berdampak secara sosial pada penerima bantuan, yaitu pada kaum minoritas dari penerima bahwa bantuan yang diterima berkontribusi dalam bisnis usaha. (Marini, n.d.).

Dampak bantuan secara ekonomi, yaitu penerima bantuan dapat membantu memenuhi kebutuhan meskipun dalam peranannya masih kurang efektif dikarenakan beberapa faktor. Pertama, bantuan bersifat sementara dan jumlah yang diberikan masih tergolong kecil. Kedua, kebijakan bantuan langsung tunai yang ada pada masa pandemi Covid-19 tidak sesuai dengan keadaan masyarakat dan dirasa tidak efektif dikarenakan masyarakat berada di bawah garis kemiskinan yang tinggi dan sangat membutuhkan bantuan. (Wowiling, n.d.). Bantuan yang diberikan tidak memenuhi kebutuhan primer masyarakat di masa pandemi Covid-19 (Citra, n.d.). Berbeda halnya dengan dampak bantuan kepada kepala rumah tangga di bagian Indonesia Timur, bantuan yang diberikan 
dapat didedikasikan pada perubahan konsumsi pangan penerima bantuan pada rumah tangga (Amrullah et al., 2020).

\section{METODE PENELITIAN}

Dalam penelitian ini, peneliti bertujuan untuk mengetahui apakah Banpres kepada UMKM tepat sasaran atau tidak menimbang terjadinya kontraksi pada laju pertumbuhan ekonomi di Daerah Istimewa Yogyakata. Terjadinya kontraksi atau penurunan yang drastis pada 2020 yang sangat berdampak besar dalam sektor perekonomian Indonesia yang disebabkan oleh pandemi Covid-19 (Badan Pusat Statistika DIY, 2020). Kontraksi yang terjadi pada laju ekonomi tersebut, memberikan dampak terhadap berjalannya UMKM di Daerah Istimewa Yogyakarta. Penelitian menggunakan metode kualitatif eksploratif, yaitu metode yang menjelaskan serta menginvestigasi lebih mendalam terhadap proses, makna, serta konteks yang akan diteliti serta memberikan keluasan bagi peneliti untuk menganalisis kasus atau multikasus secara mendalam dan detail (Al-Hamdi et al., 2020). Penelitian ini menggunakan data sekunder dari media cetak, media online, website pemerintah pusat dan pemerintah Kabupaten Sleman, Badan Pusat Statistika Daerah Istimewa Yogyakarta dan Badan Pusat Statistika Sleman, serta didukung oleh artikel jurnal nasional dan internasional yang berkaitan dengan UMKM di Indonesia selama pandemi COVID-19. Data-data yang didapatkan dilakukan penyaringan dengan tujuan untuk memfokuskan penelitian terhadap permasalahan Banpres kepada UMKM di Kabupaten Sleman selama pandemi Covid-19 (Indayani \& Hartono, 2020).

Pendekatan yang digunakan yaitu pendekatan studi kasus instrumental tunggal yaitu pendekatan berfokus pada satu kasus saja bertujuan untuk membongkar kasus tersebut hingga mengetahui penyebab tidak tepat sasarannya bantuan mikro kepada penerimanya. Lokasi penelitian yaitu di Kabupaten Sleman, Daerah Istimewa Yogyakarta. Alasan memilih lokasi di Yogyakarta diantaranya karena pertumbuhan PDRB DIY yang mengalami kontraksi dari awal triwulan 2020 dan Kabupaten Sleman merupakan salah satu kabupaten yang dipilih untuk penelitian. Dari penelitian ini, peneliti dapat memberikan hasil analisis dari keefektivitasan Banpres masa pandemi Covid-19 dalam meningkatkan laju ekonomi nasional, khususnya di Kabupaten Sleman, serta mengetahui alur penyaluran bantuan agar dapat dijadikan sebagai evaluasi untuk Banpres ke depannya yang bersifat dinamis.

\section{HASIL DAN PEMBAHASAN}

Pandemi Covid-19 menjadi konsentrasi besar bagi Indonesia terutama bagi keberlangsungan perekonomian. Permasalahan yang terjadi pada perekonomian Indonesia berdampak bagi laju perekonomian di Sleman Daerah Istimewa Yogyakarta. Data (Badan Pusat Statistika DIY, 2020) menunjukkan bahwa Laju Perekonomian DIY mengalami kontraksi pada 2020 dibandingkan dengan 2019. Kontraksi yang terjadi sebesar 2,84 disebabkan karena situasi pandemi Covid-19. Kontraksi yang terjadi pada triwulan II 2020 menunjukkan bahwa situasi ekonomi di DIY mengalami kontraksi yang cukup tajam saat pandemi Covid-19 mulai memasuki Indonesia dan mulai menyebar ke seluruh daerah di Indonesia. Kontraksi tidak dapat dihindarkan dikarenakan program Pembatasan Sosial Berskala Besar (PSBB) yang menghambat sementara proses perekonomian dan berfokus kepada pencegahan penyebaran Covid-19. Kontraksi dan depresiasi rupiah merupakan salah satu faktor memperlambat pertumbuhan ekonomi (Raharja, n.d.). 


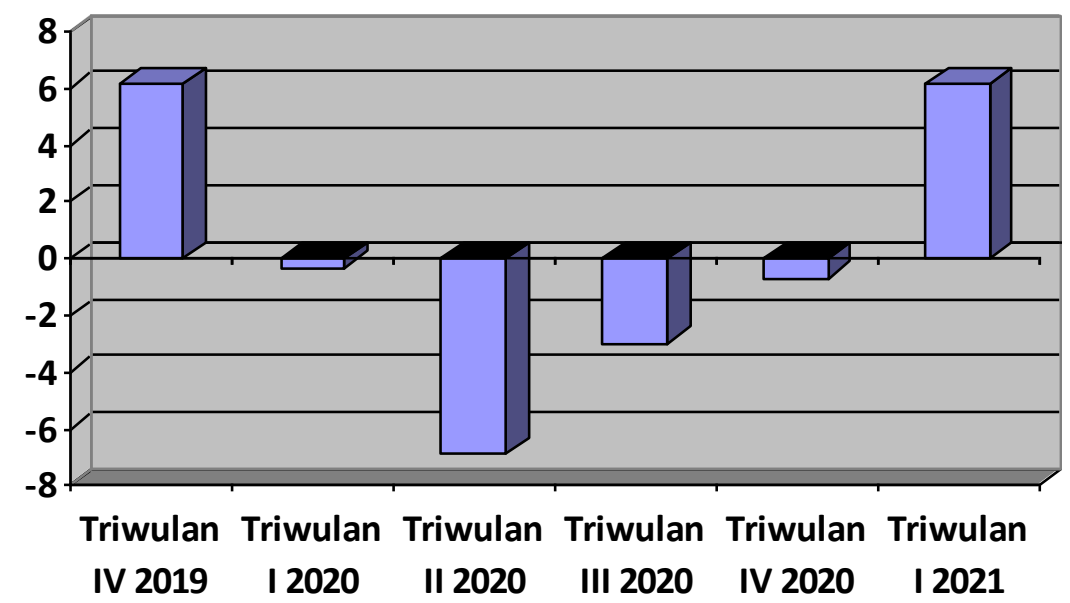

Gambar 1. Pertumbuhan PDRB Triwulan Daerah Istimewa Yogyakarta (y-on-y) 2019-2021

Sumber: Badan Pusat Statistika DIY, 2021

Kontraksi laju perekonomian di Sleman berdampak pada nilai Produk Domestik Bruto Indonesia yang mengalami penurunan pada 2020 (Modjo, 2020). Pada 2019 diperoleh bahwa pertumbuhan PDB di angka 4,97 dan pada 2020 mengalami penurunan jika dilihat selama lima tahun terakhir (gambar 1). Penurunan PDB ini disebabkan karena situasi Indonesia pada awal 2020 dan pandemi Covid-19 menjadi salah satu situasi yang tidak diharapkan oleh perekonomian Indonesia (Hendro \& Jessen, 2021). Hal tersebut berdampak sangat besar di kancah ekonomi Internasional-Indonesia. UMKM berperan sebagai penopang tumbuhnya perekonomian nasional (Marlinah, 2020). Dampak yang ditimbulkan dari kontraksi pertumbuhan Produk Domestik Bruto hingga laju perekonomian di Sleman menunjukkan bahwa UMKM memiliki peran di dalam laju perekonomian Indonesia (Badan Pusat Statistika DIY, 2020). Dampak yang dialami UMKM selama pandemi Covid-19 dikaitkan oleh beberapa permasalahan. Sektor pariwisata misalnya pada masa pandemi Covid-19, pemerintah memberlakukan pembatasan pada sektor wisata yang menyebabkan menurunnya jumlah wisatawan lokal hingga mancanegara (Priyanto et al., 2020).

Akibat turunnya tingkat kedatangan wisatawan berdampak pula pada turunnya omzet para UMKM, terutama yang menjajakan oleh-oleh khas daerah. Tidak hanya membatasi orang lokal untuk berwisata, Daerah Istimewa Yogyakarta merupakan kota yang dipenuhi oleh mahasiswa dari luar kota maupun provinsi di Indonesia. Dengan adanya situasi pandemi Covid-19, mahasiswa memilih melakukan pembelajaran secara daring di kampung masing-masing. Dengan berkurangnya mahasiswa yang ada di Yogyakarta membuat UMKM yang berada di sekitar kampus atau sekolah mengalami penurunan omzet hingga gulung tikar karena tidak adanya pelanggan. Penurunan PDB Indonesia menjadi salah satu faktor bahwa ekonomi Indonesia memiliki situasi yang tidak dalam keadaan baik pada masa pandemi Covid-19.

Tabel 1. Pertumbuhan Ekonomi Menurut Kategori UMKM

\begin{tabular}{|clcc|}
\hline NO & Kategori & Triwulan III 2020 & Triwulan I 2021 \\
\hline 1. & Industri & $-5,36$ & 0,45 \\
2. & Pertanian & 7,49 & 10,86 \\
\hline
\end{tabular}




\begin{tabular}{|rccc|}
\hline NO & Kategori & Triwulan III 2020 & Triwulan I 2021 \\
\hline 3. & Konstruksi & $-12,19$ & 31,91 \\
4. & Infokom & 17,83 & 11,40 \\
5. & Jasa & 3,85 & $-2,13$ \\
& Pendidikan & $-18,82$ & 5,81 \\
6. & Akomodasi & $-4,70$ & $-0,21$ \\
7. & Perdagangan & $-4,39$ & 0,56 \\
8. & Administrasi & & \\
& Pemerintah & 3,93 & $-1,46$ \\
9. & Real Estate & $-22,98$ & $-12,01$ \\
10. & Transportasi & $-1,80$ & 0,27 \\
11. & Jasa Keuangan & 21,85 & 10,93 \\
12. & Jasa Kesehatan & $-23,37$ & 5,38 \\
13. & Jasa Lainnya & $-11,37$ & 4,58 \\
14. & Jasa & & \\
& Perusahaan & $-10,60$ & $-3,05$ \\
15. & Pertambangan & 1,81 & $-5,72$ \\
16. & Listrik dan Gas & Pengadaan Air & 18,24 \\
17. & Pan & \\
\hline
\end{tabular}

Sumber: Badan Pusat Statistika DIY, 2020, 2021

Data Tabel 1 menunjukkan bahwa ada 10 dari 17 lapangan usaha mengalami kontraksi pada 2020. Pada kategori perdagangan, UMKM masuk ke dalam kategori perdagangan dari makanan hingga barang yang mengalami kontraksi sebesar 4,70. Hal ini disebabkan adanya pemberlakuan PSBB hingga Pembatasan Kegiatan Masyarakat (PPKM). Tidak hanya itu, pandemi Covid-19 juga berdampak pada transportasi yang memiliki keterkaitannya dengan berjalannya UMKM. Transportasi dari distribusi bahan baku utama usaha UMKM hingga distribusi produksi pun mengalami kendala. Jika distribusi bahan baku terkendala akan berkaitan dengan harga dari bahan baku tersebut yang akan naik dan harga-harga barang di pasaran menjadi tidak terkendali.

Adapun rincian dari bantuan sosial yang disiapkan oleh pemerintah dalam upaya menyelamatkan perekonomian masyarakat melalui Program Pemulihan Ekonomi Nasional (PEN) berbentuk bantuan tunai, sembako, permodalan UMKM. Adapun program yang diberikan kepada masyarakat antara lain seperti: (1) Program Keluarga Harapan, target 10 juta penerima manfaat, disiapkan uang sebesar Rp37,4 triliun dan sudah direalisasikan sebesar Rp29,13 triliun atau 77,9\% per 4 September 2020; (2) Bantuan Presiden Produktif Usaha Mikro, ditargetkan 12 juta pengusaha mikro dan telah diberikan sebesar Rp13,4 triliun atau 9\% dari Rp22 triliun per 10 September 2020; (3) Bantuan Subsidi Upah Pekerja di Bawah Rp5 juta, baru tersalurkan sebanyak Rp3,6 triliun (9,5\%) dari Rp37,87 triliun. Targetnya adalah peserta BPJSTK sebanyak 15,7 juta peserta; (4) Bansos Tunai Luar Jabodetabek dengan target sebanyak 1,18 juta orang, sudah direalisasikan sebesar 67,3\% atau Rp21,82 triliun dari Rp32,4 triliun yang dijanjikan pemerintah; (5) Bansos Tunai Program Kartu Sebako Non PKH, dengan jumlah uang sebanyak Rp4,5 triliun dan sudah disalurkan seluruhnya kepada Kelompok Penerima Manfaat (KPM); (6) Bansos Sembako Jabodetabek dengan target 4,2 juta orang, sudah terealisasi sebesar 57,2\% (Rp3,82 triliun dari Rp6,8 triliun) per 4 September 2020; (7) Penyaluran Pinjaman Koperasi melalui Lembaga Pengelolaan Dana Bergulir UMKM, telah direalisasi sebesar Rp670 miliar (67\%) per 6 
September 2020 dari Rp1 triliun dengan target 100 koperasi; (8) Kartu Pekerja dengan target sebanyak 5,6 juta orang, bantuan diberikan pemerintah sebanyak Rp20 triliun, dan baru diberikan Rp10,93 triliun (54,7\%); (9) Diskon Listrik (450VA dan 900VA) yang direncanakan untuk 33,64 juta pelanggan, program yang hingga Desember 2020 diestimasi menghabiskan Rp12,18 triliun (79,1\%) dari Rp15,4 triliun; (10) Bantuan Langsung Tunai Dana Desa, dengan target 12,3 juta kepala keluarga dan telah diberikan sebesar Rp10,50 triliun per September 2020 dengan jumlah bantuan keseluruhan sebesar Rp31,80 triliun (Ramadhani \& Megawati, 2021).

Untuk menindaklanjuti dampak yang terjadi akibat pandemi Covid-19, pemerintah mengeluarkan Banpres atau Bantuan Langsung Tunai kepada pelaku UMKM di Kabupaten Sleman. Banpres merupakan kebijakan yang dilakukan menurut Peraturan Menteri Koperasi, Usaha Kecil, dan Menengah Republik Indonesia Nomor 6 Tahun 2020 untuk memberikan bantuan berupa uang tunai dengan tujuan bantuan tersebut digunakan untuk membantu masyarakat yang mengalami krisis keuangan atau modal (Marini, n.d.). Berdasarkan data yang telah diperoleh dari (Dinas Koperasi dan UMKM Sleman, 2020) sebanyak 2.162 pelaku UMKM di Kabupaten Sleman menerima bantuan tersebut. Data yang diperoleh di Dinas Koperasi dan UMKM Sleman menunjukkan pelaku UMKM mendaftarkan usaha mereka di Dinas. Calon penerima bantuan ini dilakukan dan diberikan kepada UMKM yang telah mendaftarkan usaha mereka di Dinas Koperasi dan UMKM. Berdasarkan Tabel 1 data BPS DIY triwulan III 2020 dengan data BPS triwulan I 2021 menunjukkan titik terang bahwa pertumbuhan ekonomi DIY mengalami pertumbuhan sebesar 6,14\%. Dari 17 kategori UMKM, sebanyak 12 kategori UMKM yang mengalami kenaikan. Setelah adanya Banpres atau BPUM dapat menopang dan menaikkan pertumbuhan ekonomi DIY yang mengalami kontraksi di awal 2020. Selain itu, Banpres berupa uang tunai kepada UMKM dapat digunakan untuk membantu UMKM yang mengalami krisis modal.

Berdasarkan (Dinas Koperasi dan UMKM Sleman, 2020), total UMKM yang berada di Kabupaten Sleman Daerah Istimewa Yogyakarta menunjukkan terdapat 52.671 UMKM terdaftar dalam file rekapitulasi data UMKM hingga 2020. Hal ini membuktikan bahwa penyaluran Banpres harus terlaksana dengan merata dan tanpa adanya kecurangan pihak tertentu. Pihak tertentu merupakan pelaku UMKM yang tidak bermasalah dalam permasalahan modal usaha dan penjualan yang stabil. Rekapitulasi yang ada (Dinas Koperasi dan UMKM Sleman, 2020) menunjukkan bagaimana pemerintah harus serius dalam memilah data kepada usaha mana yang dapat menerima bantuan. Lebih baik jika pemerintah dapat turun langsung di lapangan untuk melakukan monitoring secara langsung terhadap usaha yang dijalani para pelaku usaha agar dalam dapat dipertimbangkan berdasarkan fakta atau realitas di lapangan. Kompetensi monitoring dibutuhkan dalam pemantauan hingga evaluasi dari kebijakan atau program yang dilakukan untuk menjaga agar suatu kebijakan yang akan diimplementasikan sesuai dengan sasaran dan tujuan, dapat menemukan kesalahan sejak dini untuk meminimalkan risiko yang besar, hingga dapat mengetahui tingkat efektivitas suatu program atau kebijakan berhasil atau tidaknya dalam mencapai tujuan (Marlinah, 2020).

Bantuan Banpres kepada pelaku UMKM digunakan sebagai modal penyelamat dalam mempertahankan usaha mereka di tengah pandemi Covid-19 (Rozzaq \& Widiyarta, 2021). Dengan adanya Banpres, pelaku UMKM dapat memanajemen keuangan mereka pada situasi pandemi dan juga sebagai pemulihan dari ekonomi nasional Indonesia. Bantuan berupa uang tunai senilai Rp2,4 juta yang ditargetkan untuk setiap UMKM dan diberikan 
uang tunai melalui rekening bank masing-masing yang telah bekerja sama dengan pemerintah. Banpres tersebut hanya bisa diterima sekali oleh UMKM. Jika calon penerima tidak mendapatkan Banpres masih bisa mencalonkan diri di gelombang berikutnya. Faktanya, pada tahapan penyaluran Banpres kepada pelaku usaha UMKM di wilayah Sleman diperoleh bahwa program kebijakan tidak efektif. Beberapa kelurahan di Sleman mengajukan pengusulan calon penerima dengan kurang memperhatikan pelaku UMKM yang membutuhkan bantuan tersebut. Asumsi diperkuat dengan pengakuan dari Presiden Jokowi dalam forum peresmian pembukaan rapat koordinasi nasional pengawasan intern pemerintah tahun 2021 di Istana Kepresidenan Bogor yang menjelaskan bahwa data-data yang digunakan tidak sinkron antara data pemerintah pusat dengan data pemerintah daerah (Rusiana, 2021). Hal ini membuktikan bahwa dalam penyaluran bantuan tersebut tidak menggunakan data yang akurat dan perlunya meningkatkan kualitas data antara pusat dengan daerah. Akan lebih baik jika pemerintah dapat turun langsung di lapangan untuk melihat usaha yang dijalani para pelaku usaha agar dapat dipertimbangkan berdasarkan fakta atau realitas di lapangan.

Diketahui bahwa usaha mikro merupakan usaha yang dimiliki oleh perorangan atau badan usaha perorangan dengan memiliki kriteria memiliki penjualan tahunan atau omzet sebesar 300 juta (Suci, 2017). Diperkuat dengan (Undang-Undang Republik Indonesia Nomor 20 Tahun 2008 Tentang Usaha Mikro, Kecil, dan Menengah, n.d.) Usaha Kecil merupakan usaha yang didirikan oleh perorangan atau badan usaha tetapi tidak termasuk ke dalam anak perusahaan dengan kriteria memiliki penjualan tahunan atau omzet lebih dari Rp300 juta hingga Rp2,5 miliar. Usaha menengah yaitu usaha yang dimiliki oleh perorangan atau badan usaha tetapi tidak termasuk kedalam anak perusahaan yang dimiliki secara langsung maupun tidak langsung dengan Usaha Kecil dengan kriteria memiliki penjualan tahunan atau omzet lebih dari Rp2,5 miliar hingga Rp50 miliar.

Berdasarkan (Peraturan Menteri Koperasi, Usaha Kecil, dan Menengah Republik Indonesia Nomor 6 Tahun 2020 Tentang Pedoman Umum Penyaluran Bantuan Pemerintah Bagi Pelaku Usaha Mikro untuk Mendukung Pemulihan Ekonomi Nasional pada Masa Pandemi Covid-19, n.d.) adanya multitafsir oleh beberapa orang dalam menerjemahkan peraturan dikarenakan harus adanya pernyataan yang perlu dilakukan oleh Dinas Koperasi dan UMKM untuk dapat dijelaskan lebih rinci dan detail mengenai kriteria penerima bantuan. Bantuan berupa uang tunai senilai Rp2,4 juta diberikan dan dikirim melalui rekening penerima bantuan setiap UMKM. Banpres tersebut hanya bisa diterima sekali oleh UMKM, jika calon penerima tidak mendapatkan Banpres masih bisa mencalonkan diri di gelombang berikutnya. Untuk pencalonan UMKM, masih kurang informasi secara detail bagaimana calon penerima bantuan dapat mencalonkan diri untuk kali kedua pada gelombang selanjutnya. Hal tersebut juga ditandai oleh beberapa penyebab. Pertama, kognisi yaitu pemahaman aparatur di kabupaten, kecamatan, kelurahan, dan RT atau RW terhadap kebijakan program bantuan presiden kepada UMKM. Kedua, arahan dari kabupaten terhadap penyelenggaraan dan penyaluran Banpres kepada pelaku UMKM yang ingin mendapatkan bantuan tersebut. Ketiga, dalam kebijakan Menteri Sosial Nomor 54/HUK/2020 tidak dijelaskan secara rinci mengenai kriteria yang mendapatkan bantuan tersebut (Mufida, 2021).

Adanya pelaku usaha yang tidak mengetahui informasi Banpres dikarenakan ada beberapa oknum di masyarakat yang tidak memberikan informasi tersebut ke masyarakat luas, tetapi hanya orang-orang tertentu yang mengetahui bantuan. Minimnya informasi yang didapatkan juga dialami di Kelurahan Bukit Cermin, sosialisasi bantuan dana kriteria 
menjadi calon penerima bantuan tidak dilakukan secara merata kepada masyarakat (Haryanti, 2015). Tidak semua pelaku UMKM dapat mengakses informasi offline maupun online, dikarenakan ada beberapa pelaku UMKM yang tidak aktif dalam mencari informasi. Hal ini ditandai dengan adanya beberapa pelaku UMKM yang tidak mahir dalam menggunakan smartphone dan sosial media. Dalam hal ini terkait informasi atau pemberitahuan yang ditujukan kepada seluruh pelaku usaha kurang maksimal terhadap pengusulan calon bantuan presiden. Rekomendasi yang diberikan yaitu dengan melibatkan aktor pejabat kelurahan setempat untuk menyelenggarakan sebuah musyawarah desa atau sosialisasi bagi UMKM untuk pengusulan calon penerima Banpres. Basis data yang digunakan untuk mempermudah yaitu dengan data yang diinput oleh kelurahan tidak melalui individu UMKM karena dapat mempermudah oknum lain mendaftar calon penerimaan bantuan. Syarat yang diberikan kepada kelurahan harus sesuai dengan menambahkan foto usaha yang dijalankan oleh UMKM dan dengan aktif dari kelurahan setempat untuk melayani calon penerima bantuan. Distribusi program bantuan tidak pernah mudah dan umumnya disebabkan oleh kurangnya kesiapan partai yang mendistribusikan bantuan, yaitu pemerintah dan masalah dapat mulai dari pengumpulan data sampai penerima bantuan. Menurut (Barany \& Simanjuntak, 2020) berpendapat bahwa setidaknya ada empat aspek utama yang perlu diperhatikan dipertimbangkan sehingga distribusi program bantuan dapat berjalan secara efektif dan efisien yakni cakupan bantuan, skema bantuan, durasi pandemi, kesiapan pemerintah, dan mekanisme distribusi bantuan. Tidak tepat sasarannya bantuan juga dialami Kecamatan Gampong, Banda Aceh yaitu kurang efektifnya bantuan dikarenakan minimnya informasi yang diterima oleh pelaku atau calon penerima di kelurahan, terlebih lagi mekanisme kebijakan yang belum ada terkait dengan penyaluran dana dan dibutuhkan peraturan dari pemerintah mengenai maladministrasi yang terjadi (Suari \& Giri, 2021). Kelurahan merupakan salah satu wilayah yang strategis karena cakupan wilayah yang masih bersifat sempit dan efektif jika pengusulan calon di kelurahan baik dan sesuai.

Selain musyawarah desa dan keaktifan kelurahan dalam melayani pencalonan penerima bantuan, rekomendasi lain yang diberikan yaitu data atau formulir yang selama ini digunakan pemerintah lebih baik diubah menjadi turun ke lapangan untuk mendata secara langsung UMKM yang masih beroperasi dengan UMKM yang membutuhkan bantuan tersebut dijadikan sebagai bantuan modal mereka untuk mempertahankan usaha di tengah pandemi Covid-19. Pendataan calon penerima bantuan secara langsung di lapangan tepat sasaran di kecamatan Sulun, Minahasa Selatan. Cara pendataan yang dilakukan dengan mendata langsung di RT atau RW secara transparan serta adil. Pendataan juga dilakukan dengan menimbang mekanisme yang telah ditentukan (Maun, n.d.). Untuk melakukan verifikasi data pada pengusulan data, perlu adanya data yang terkoneksi dari pusat ke daerah secara sinkron dan termutakhir. Selanjutnya, setelah adanya sinkronisasi data tersebut dari pemerintah pusat, pemerintah daerah memberikan verifikasi melalui formulir online. Formulir ini akan disatukan bersama data-data pelaku UMKM yaitu menyangkut harapan atau kegunaan dari adanya bantuan tersebut kepada pelaku UMKM serta menyertakan bukti foto usaha yang dijalankan pada formulir tersebut. Hal ini bisa dijadikan sebagai monitoring dan evaluasi bagi pemerintah daerah agar dalam pemberian Banpres seniai Rp2,4 juta dapat diberikan kepada UMKM yang membutuhkan bantuan tersebut.

Kriteria yang digunakan pada penerima bantuan pemerintah (Kusumawardhany, 2020) yaitu dominan berdasarkan pada kriteria status pekerjaan kepala keluarga, selain itu 
status lain dapat digunakan sebagai tolak ukur dalam kriteria ketepatan sasaran bantuan pemerintah yaitu dengan memperhatikan status pekerjaan istri, status rumah, dan jumlah tanggungan. Beberapa kriteria yang digunakan dalam penyaluran Banpres kepada pelaku UMKM perlu dilakukan berdasarkan kriteria status dari pelaku UMKM dan memperhatikan kriteria pendapatan pelaku UMKM terhadap berjalannya bisnis. Dalam pengusulan calon penerima bantuan yang dilakukan tidak menggunakan bukti pendapatan yang didapatkan oleh pelaku UMKM. Pada penyaluran bantuan, hal tersebut menjadi kurang efektif jika dikomparasikan dengan kriteria ketepatan sasaran bantuan pemerintah dengan menggunakan kriteria status pengusul bantuan.

\section{PENUTUP}

UMKM termasuk ke dalam sektor ekonomi nasional yang harus dikembangkan serta diberdayakan agar UMKM bisa memberikan kontribusinya untuk pertumbuhan ekonomi nasional. Banpres kepada UMKM di Kabupaten Sleman merupakan wujud dari kebijakan pemerintah kepada berlangsungnya ekonomi nasional Indonesia. Kebijakan tersebut juga dilihat dari laju perekonomian serta nilai PDRB yang mengalami kontraksi. Banpres yang diberikan kepada pelaku UMKM kurang efektif terlebih bahwa dalam penyaluran bantuan belum menggunakan kriteria status dari pelaku usaha pengusul. Peran aparatur di kabupaten, kecamatan, kelurahan, dan RT atau RW terhadap kebijakan program bantuan presiden kepada UMKM perlu ada dalam pemahaman aparatur dan arahan dari kabupaten terhadap penyelenggaraan dan penyaluran Banpres kepada pelaku UMKM yang ingin mendapatkan bantuan tersebut. Hal tersebut ditandai dengan kurangnya pertimbangan bahwa tidak semua pelaku UMKM dapat mengakses informasi offline maupun online karena ada beberapa pelaku UMKM yang tidak aktif dalam mencari informasi. Hal ini ditandai dengan adanya beberapa pelaku UMKM tidak mahir dalam menggunakan smartphone dan media sosial. Informasi atau pemberitahuan terkait pengusulan calon bantuan presiden yang ditujukan kepada seluruh pelaku usaha pun menjadi kurang maksimal. Penyaluran bantuan kurang efektif jika dikomparasikan dengan kriteria ketepatan sasaran bantuan pemerintah dengan menggunakan kriteria status pengusul bantuan, ditandai dengan ketidakjelasan tolak ukur kriteria penerima bantuan yang digunakan menurut peraturan menteri koperasi dan UMKM. Rekomendasi yang diberikan penulis yaitu dengan melibatkan aktor pejabat kelurahan setempat untuk menyelenggarakan sebuah musyawarah desa atau sosialisasi bagi UMKM untuk pengusulan calon penerima bantuan presiden. Basis data yang digunakan agar mempermudah yaitu melalui data yang diinput oleh kelurahan dan bukan oleh individu UMKM. Hal ini karena berpotensi oknum lain mendaftar calon penerimaan bantuan dan pencalonan penerima bantuan. Solusinya, data yang digunakan oleh pemerintah dapat dikumpulkan melalui kelurahan yang turun langsung ke lapangan untuk melakukan pendataan UMKM hingga penggunaan database secara terpusat.

\section{DAFTAR PUSTAKA}

\section{Artikel atau Jurnal}

Akib, H. 2012. "Implementasi Kebijakan: Apa, Mengapa dan Bagaimana". Jurnal Ilmiah Ilmu Administrasi Publik, 1(1), 1. https://doi.org/10.26858/jiap.v1i1.289 [Diakses 27 Mei 2021] 
Alauddin, LC, M. 2019. Fungsi UMKM dalam Meningkatkan Perekonomia Masyarakat. 5, 80-90. [Diakses 30 Mei 2021]

Alfiarini, A., \& Primadasa, Y. 2020. "Penerapan Metode Multi Attribute Utility Theory untuk Menganalisa Pemberian Bantuan Raskin". Techno.Com, 19(1), 76-86. https://doi.org/10.33633/tc.v19i1.3136. [Diakses 30 Mei 2021]

Alfrian, G. R., \& Pitaloka, E. 2020. Strategi Usaha Mikro, Kecil, dan Menengah (UMKM) Bertahan pada Kondisi Pandemik Covid-19 di Indonesia. 6(2), 8. [Diakses 30 Mei 2021]

Amrullah, E. R., Pullaila, A., Hidayah, I., \& Rusyiana, A. (n.d.). "Dampak Bantuan Langsung Tunai Terhadap Ketahanan Pangan Rumah Tangga di Indonesia". Jurnal Agro Ekonomi, 38(2), 14. [Diakses 25 Mei 2021]

Auliya, A. N., \& Arif, L. 2021. Peran Dinas Koperasi Usaha Mikro Perindustrian dan Perdagangan dalam Penanganan Dampak Pandemi Covid-19 pada Usaha Mikro Di Kabupaten Gresik. 8(1), 10. [Diakses 22 Mei 2021]

Chandra, W. 2020. Perubahan Sistem Pelayanan Makanan Pada Usaha Kuliner Selama Masa Pandemi Covid-19 dan Era Kebiasaan Baru di Kota Makassar. 6, 8. [Diakses 20 Mei 2021]

Citra, S. F. (n.d.). Analisis Kesesuaian Penerima dan Penggunaan Dana Bantuan Sosial Pandemi Covid-19 pada Masyarakat Gampong Sapik dan Gampong Air Berudang, Aceh Selatan. 12. [Diakses 20 Mei 2021]

Dewi, A., Nurmandi, A., Rochmawati, E., Purnomo, E. P., Rizqi, M. D., Benedictos, S., Suardi, W., \& Dewi, D. T. K. 2020. Global policy responses to the COVID-19 pandemic: Proportionate adaptation and policy experimentation: A study of country policy response variation to the COVID-19 pandemic. 10(4), 7. [Diakses 20 Mei 2021]

Effendi, G. N., Purnomo, E. P., \& Malawani, A. D. 2020. "Cash For Work? Extreme Poverty Solutions Based on Sustainable Development". JEJAK, 13(2), 381-394. https:// doi.org/10.15294/jejak.v13i2.25448. [Diakses 30 April 2021]

Firdaus, \& Rakhmat. 2019. Dinamika ImplementasiI Kebijakan Penanggulangan Kemiskinan Di Indonesia. 1, 1-6. [Diakses 5 Mei 2021]

Hamdala, T., \& Esabella, S. 2020. "Rancang Bangun Aplikasi Monitoring dan Evaluasi Penyaluran Dana Sosial di Dinas Sosial Kabupaten Sumbawa Berbasis Web". Jurnal Informatika, Teknologi dan Sains, 2(2), 105-111. https:/ / doi.org/10.51401/jinteks.v2i2.591. [Diakses 3 Mei 2021]

Haryanti, N. D. 2015. Implemantasi Bantuan Langsung Tunai (BLT) di Kecamatan Tanjungpinang Barat Kelurahan Bukit Cermin Kota Tanjungpinang Tahun 2012. 19. [Diakses 30 April 2021]

Hendro, \& Jessen. 2021. Penyebab Penurunan dan Solusi Pemulihan PDB Indonesia di Masa Pandemi Covid-19. 2. [Diakses 5 Mei 2021]

Hutagalung, B. T., Siregar, E. T., \& Lubis, J. H. 2021. Penerapan Metode SMART dalam Seleksi Penerima Bantuan Sosial Warga Masyarakat Terdampak COVID-19. 5, 12. [Diakses 30 April 2021]

Indayani, S., \& Hartono, B. 2020. Analisis Pengangguran dan Pertumbuhan Ekonomi sebagai Akibat Pandemi Covid-19. 18(2), 8. [Diakses 5 Mei 2021]

Kembuan, M. E. L., Lengkong, F. D. J., Kolondam, H., \& Londa, V. Y. (n.d.). Implementasi Kebijakan Pendistribusian Dana Sosial Banjir di Kecamatan Tikala Kota Manado. 12. [Diakses 30 Mei 2021]

Khomaini, A. A. (n.d.). Dampak Program antuan Tunai (Cash Transfer) Terhadap Kesejahteraan Subjektif di Indonesia. 5, 1-16. [Diakses 25 Mei 2021] 
Kusumawardhany, N. (n.d.). Penerapan Metode Analytical Hierarcy (AHP) dan Simple Additive Weighting (SAW) untuk Penentuan Penerima Bantuan Sosial Pandemi Covid-19. 5. [Diakses 25 Mei 2021]

Leckel, A., Veilleux, S., \& Dana, L. P. 2020. "Local Open Innovation: A means for public policy to increase collaboration for innovation in SMEs". Technological Forecasting and Social Change, 153, 119891. https://doi.org/10.1016/j.techfore.2019.119891. [Diakses 22 Mei 2021]

Lukitasari, S. W., Sulasmono, B. S., \& Iriani, A. 2017. Evaluasi Implementasi Kebijakan Pendidikan Inklusi. Kelola: Jurnal Manajemen Pendidikan, 4(2), 121. https:/ / doi.org/10.24246/j.jk.2017.v4.i2.p121-134. [Diakses 20 Mei 2021]

Marini, D. (n.d.). Dampak Penyaluran Bantuan Langsung Tunai (BLT) Terhadap Masyarakat Miskin di Desa Perawang Barat Kecamatan Tualang Kabupaten Siak. 10. [Diakses 20 Mei 2021]

Marlinah, L. (2020). Peluang dan Tantangan UMKM dalam Upaya Memperkuat Perekonomian Nasional Tahun 2020 di tengah Pandemi Covid 19. 22, 1-7. [Diakses 20 Mei 2021]

Maun, C. E. F. (n.d.). Efektivitas Bantuan Langsung Tunai Dana Desa Bagi Masyarakat Miskin Terkena Dampak Covid-19 di Desa Talaitad Kecamatan Suluun Tareran Kabupaten Minahasa Selatan. 16. [Diakses 15 Mei 2021]

Modjo, M. I. (2020). Memetakan Jalan Penguatan Ekonomi Pasca Pandemi. 2, 14.

Mondong, H. (n.d.). Peran Pemerintah Desa dalam Meningkatkan Partisipasi Masyarakat dalam Pembangunan Desa. 18. [Diakses 15 Mei 2021]

Mufida, N. (2021). Efektivitas Bantuan Sosial Tunai di Kelurahan Purwosari Kecamatan Purwosari Kabupaten Pasuruan. Jurnal Sosial Sains, 1(2). https:/ / doi.org/10.36418/sosains.v1i2.23. [Diakses 20 Mei 2021]

Mutiarin, D., Fathani, A. T., Sakir, S., \& Atmojo, M. E. 2020. Performance-Based Budgeting Review from Local Government Budget: West Sumatra in 2017-2018. Journal of Governance and Public Policy, 7(3). https:// doi.org/10.18196/jgpp.73133. [Diakses 10 Mei 2021]

Nur Aini, \& Mundir, A. 2020. "Pengelolaan Zakat, Infaq dan Sedekah dalam Upaya Meningkatkan Pendapatan Ekonomi Pelaku UMKM di BAZNAS Kota Pasuruan." MALIA (TERAKREDITASI), 12(1), 95-108. https://doi.org/10.35891/ml.v12i1.2367. [Diakses 20 Mei 2021]

Pakpahan, A. K. 2020. COVID-19 dan Implikasi Bagi Usaha Mikro, Kecil, dan Menengah. 1-6. [Diakses 20 Mei 2021]

Panjaitan, E., Dewi, R., \& Angelia, N. 2019. "Peranan Pemerintah Desa dalam Meningkatkan Kualitas Pelayanan Administrasi kepada Masyarakat". PERSPEKTIF, 8(1), 32. https://doi.org/10.31289/perspektif.v8i1.2543. [Diakses 20 Mei 2021]

Priyanto, A., Purnomo, E. P., Andoko, B. W., Khairina, E., \& Fadhlurrohman, M. I. 2020. "The Impact of Covid-19 on Localtourism Sector and Income". MIMBAR : Jurnal Sosial Dan Pembangunan, 36(2). https://doi.org/10.29313/mimbar.v36i2.6033. [Diakses 15 Mei 2021]

Putra, T. G. 2015. Peran Pemerintah Daerah Dan Partisipasi Pelaku Usaha dalam Pengembangan UMKM Manik-Manik Kaca di Kabupaten Jombang. 3, 10. [Diakses 10 Mei 2021]

Putra, Y. P., Purnomo, E. P., Suswanta, S., \& Kasiwi, A. N. 2020. Policy Of A Merit System To Make A Good And Clean Government In The Middle Of Bureaucratic Politicization. Journal of Government and Civil Society, 4(2), 159. https:// doi.org/10.31000/jgcs.v4i2.2393. [Diakses 20 Mei 2021] 
Raharja, S. (n.d.). Perbandingan Efektifitas Kebijakan Moneter Konvensional dan Syariah dalam Menghadapi Depresiasi Rupiah dan Kontraksi Ekonomi Pada Bulan September 2015. 11. [Diakses 15 Mei 2021]

Rahmat, D. 2017. "Implementasi Kebijakan Program Bantuan Hukum Bagi Masyarakat Tidak Mampu di Kabupaten Kuningan". UNIFIKASI: Jurnal Ilmu Hukum, 4(1). https:/ / doi.org/10.25134/unifikasi.v4i1.478. [Diakses 15 Mei 2021]

Rozzaq, M., \& Widiyarta, A. 2021. "Implementasi Program Bantuan Bagi Pelaku Usaha Mikro di Kecamatan Gubeng Kota Surabaya". Journal Publicuho, 4(2). https://doi.org/10.35817/jpu.v4i2.17858. [Diakses 20 Mei 2021]

Santoso, J., Nurcahyo, H., \& Riyanta, A. B. 2020. Implementasi Paket Bantuan Sosial Sebagai Upaya Menghadapi Pandemi Covid-19. 1, 82-86. [Diakses 20 Mei 2021]

Sari, L. P., Tsara, R. L., \& Handayani, E. D. T. 2020. Purwosari Tourism Village Development Efforts Based on Local Tourism Integrated. IJDE, 2(1), 1-5. [Diakses 15 Mei 2021]

Satispi, E., DyasTuti, R. W., Fathani, A. T., \& Kaewhanam, P. 2021. "Local Government Respond to COVID-19 Pandemics: A Study of South Tangerang City." Journal of Governance and Public Policy, 8(2), 82-92. https://doi.org/10.18196/jgpp.v8i2.11439. [Diakses 20 Mei 2021]

Setiawana, A., Nurmandi, A., Purnomo, E. P., \& Muhammad, A. 2021. Disinformation and Miscommunication in Government Communication in Handling COVID-19 Pandemic. Webology, 18(1), 203-218. https:/ / doi.org/10.14704/WEB/V18I1/WEB18084/. [Diakses 20 Mei 2021]

Soares, A. 2015. Peranan Pemerintah Daerah dalam Perencanaan Pembangunan Daerah. Jurnal Ilmu Sosial dan Ilmu Politik, 4(2), 6. [Diakses 15 Mei 2021]

Soetjipto, D. H. N. (n.d.). Ketahanan UMKM Jawa Timur. 99. [Diakses 10 Mei 2021]

Suari, N. M. K. P., \& Giri, N. P. N. S. 2021. Analisis Terhadap Potensi Maladministrasi Bantuan Langsung Tunai (BLT)Dana Desa Selama Pandemi Covid-19. 9(2), 107-119. [Diakses 10 Mei 2021]

Suci, Y. R. 2017. Perkembangan UMKM (Usaha Mikro, Kecil, dan Menengah) di Indonesia. 6. [Diakses 10 Mei 2021]

Sugiri, D. 2020. "Menyelamatkan Usaha Mikro, Kecil dan Menengah dari Dampak Pandemi Covid-19". Fokus Bisnis: Media Pengkajian Manajemen dan Akuntansi, 19(1), 76-86. https:/ / doi.org/10.32639/fokusbisnis.v19i1.575. [Diakses 19 Mei 2021]

Susanti, A., Istiyanto, B., \& Jalari, M. 2020. Strategi UKM pada Masa Pandemi Covid-19. 1(2), 8. [Diakses 12 Mei 2021]

Tarmizi, A. 2018. "Strategi Pemasaran UMKM". Jurnal Riset Manajemen dan Bisnis (JRMB) Fakultas Ekonomi UNIAT, 3(2), 191-198. https://doi.org/10.36226/jrmb.v3i2.107. [Diakses 22 Mei 2021]

Ulumiyah, I., Gani, A. J. A., \& Mindarti, L. I. 2013. Peran Pemerintah Desa dalam Memberdayakan Masyarakat Desa (Studi pada Desa Sumberpasir, Kecamatan Pakis, Kabupaten Malang). 1. [Diakses 12 Mei 2021]

Valentina, T. R., Putera, R. E., \& Safitri, C. 2020. Analisis Pemanfaatan Dana Desa pada Masa Pandemi Covid-19 di Nagari Talang Anau Kabupaten Lima Puluh Kota. 2, 9. [Diakses 22 Mei 2021]

Wongkar, C. C. L., Aneke, S., \& Soepeno, M. H. (n.d.). Bantuan Langsung Tunai Pemerintah Kepada Masyarakat yang Terkena Dampak Pandemi Covid-19 (Studi di Kelurahan Kakaskasen 1)1 Oleh: Claudia Clara Lusye Wongkar2 Said Aneke-R3 Muhammad Hero Soepeno4. 4, 10. [Diakses 12 Mei 2021] 
Wowiling, R. (n.d.). Peran Pemerintah Desa dalam Penyaluran Bantuan Langsung Tunai pada Masyarakat Di Masa Pandemi Covid - 19 Di Kecamatan Maesaan Kabupaten Minahasa Selatan. 12. [Diakses 10 Mei 2021]

\section{Buku}

Al-Hamdi, R., Sakir, \& Suswanta. 2020. Penelitian Kualitatif Pegangan Mahasiswa Ilmu Pemerintahan. Yogyakarta: Pustaka Pelajar.

Purnomo, E. P., Fadhlurrohman, M. I., Salsabila, L., Fathani, A. T., Sujud, S., \& Widowaty, Y. 2021. Analysis of Sustainable Health Development Goals in Improving Public Health. In T. Antipova (Ed.), Advances in Digital Science (Vol. 1352, pp. 242-246). Springer International Publishing. https:/ / doi.org/10.1007/978-3-030-71782-7_22.

\section{Dokumen Instansi}

Badan Pusat Statistika DIY. 2020. Berita Resmi Statistik Pertumbuhan Ekonomi DIY Triwulan III2020. https://yogyakrta.bps.go.id/pressrelease/2020/11/05/1029/pertumbuhanekonomi-diy-triwulan-iii-2020.html. [Diakses 20 Mei 2021]

Badan Pusat Statistika DIY. 2021. Berita Resmi Statistik Pertumbuhan Ekonomi DIY Triwulan I2021. https://yogyakarta.bps.go.id/pressrelease/2021/05/05/1152/pertumbuhanekonomi-diy-triwulan-i-2021.html. [Diakses 12 Mei 2021]

\section{Portal Online}

Christy, F. E. 2021. Jumlah UMKM di Indonesia. https://data.tempo.co/read/1111/jumlahumkm-di-indonesia. [Diakses 1 Juni 2021]

Dinas Koperasi dan UMKM Sleman. (2020). 2.162 UMKM Sleman Peroleh Bantuan Presiden Produktif untuk Usaha Mikro. Dinas Koperasi Dan UMKM Sleman. https:/ / dinkopukm.slemankab.go.id/. [Diakses 1 Juni 2021]

Jannah, S. M. (2020, Agustus). Potensi Penyelewengan Dana Hibah untuk UMKM yang Cair Secepat Kilat. https://tirto.id/potensi-penyelewengan-dana-hibah-untuk-umkmyang-cair-secepat-kilat-fZnm. [Diakses 1 Juni 2021]

Pemerintah Kabupaten Sleman. (2016). Letak dan Luas Wilayah Kabupaten Sleman. http:/ / www.slemankab.go.id/profil-kabupaten-sleman/geografi/letak-dan-luaswilayah\#: :text=Secara\%20Geografis\%20Kabupaten\%20Sleman $\% 20$ terletak,47\%E2\% 80\% B2\% 2030\%E2\%80\% B3\%20Lintang\%20Selatan. [Diakses 1 Juni 2021]

Rusiana, D. A. (2021, Mei). Tidak Tepat Sasaran, Jokowi Minta BPKP Kawal Penyaluran Bansos. https:/ / ekbis.sindonews.com/read/438804/33/tidak-tepat-sasaran-jokowi-mintabpkp-kawal-penyaluran-bansos-1622099137. [Diakses 1 Juni 2021]

\section{Undang-Undang dan Peraturan}

Peraturan Menteri Koperasi, Usaha Kecil, dan Menengah Republik Indonesia Nomor 6 Tahun 2020 Tentang Pedoman Umum Penyaluran Bantuan Pemerintah Bagi Pelaku Usaha Mikro Untuk Mendukung Pemulihan Ekonomi Nasional Pada Masa Pandemi Covid-19. (n.d.). Retrieved March 5, 2021, from https:/ / peraturan.bpk.go.id/Home/Details/160762/ permenkop-ukm-no-6-tahun2020. [Diakses 1 Juni 2021]

Undang-Undang Republik Indonesia Nomor 20 Tahun 2008 Tentang Usaha Mikro, Kecil, dan Menengah. (n.d.). Retrieved July 7, 2021, from https://www.ojk.go.id/sustainablefinance/id/peraturan/undang-undang/Pages/Undang-Undang-Republik- 
Jurnal Wacana Kinerja

Indonesia-Nomor-20-Tahun-2008-Tentang-Usaha-Mikro,-Kecil,-dan-Menengah.aspx. [Diakses 1 Juni 2021] 